RESENHAS | REVIEWS

\title{
PACTO ANTENUPCIAL NA HERMENÊUTICA CIVIL-CONSTITUCIONAL
}

MATOS, Ana Carla Harmatiuk; TEIXEIRA, Ana Carolina Brochado. Pacto antenupcial na hermenêutica civil-constitucional. In: MENEZES, Joyceane Bezerra de; CICCO, Maria Cristina de; RODRIGUES, Francisco Luciano Lima (coord.). Direito civil na legalidade constitucional: algumas aplicações. Indaiatuba: Foco, 2021.

\section{Isabela Nabas Schiavon ${ }^{1}$}

Ana Carla Harmatiuk Matos e Ana Carolina Brochado Teixeira apresentam uma discussão sobre os limites da intervenção estatal na família que implicam em reduzir a forma como cada família deseja desenvolver as suas aspirações comuns e realização conjugal. Todavia, apontam que por intermédio dos princípios constitucionais é possível realizar uma releitura das balizas de ingerência do Estado nas relações familiares.

As autoras buscam investigar o pacto antenupcial como instrumento capaz de pactuar não somente questões patrimoniais, mas também sobre conteúdo existencial relacionado à entidade familiar, possibilitando o exercício da autonomia privada.

Abordam a compreensão civil-constitucional nas relações familiares, relembrando as transformações havidas no interior da família. A família entrou em crise com as transformações sociais ocorridas por volta do século XX, como por exemplo a revolução feminista e a inserção da mulher no mercado de trabalho. Houve uma evolução da família instituição para a família voltada para a centralidade da pessoa humana, tendo como função principal a realização existencial dos seus membros.

Nessa conjuntura da nova hermenêutica constitucional é que a autonomia privada emergiu como forma do indivíduo expressar sua liberdade sobre a maneira como deseja realizar o seu projeto de vida no âmbito familiar. O casamento deixa de ser visto como uma formalidade apta a legitimar as relações afetivas e passa a ser entendido como espaço de realização de comunhão de vida, assim como a união estável, reconhecida como entidade familiar pela Constituição.

Essa transformação na forma como a família é entendida pelo ordenamento jurídico sob a ótica civil-constitucional origina a necessidade de que seja assegurada a autonomia privada tanto nas escolhas patrimoniais, quanto existenciais do casal com o intuito de comunhão de vida, sem a interferência do legislador infraconstitucional.

Conforme as autoras, o pacto antenupcial é o instrumento negocial que precede o casamento, pelo qual o casal, no âmbito da sua liberdade e nos limites legais, pode pactuar sobre a sua comunhão de vida, criando um estatuto patrimonial em comum, esbarrando, ainda que indiretamente, na seara existencial.

\footnotetext{
${ }^{1}$ Mestranda em Direito Negocial pela Universidade Estadual de Londrina (UEL). Pós-graduanda em Direito Civil e Processo Civil pela Universidade Estadual de Londrina (UEL). Pós-graduanda em Direito Aplicado pela Escola de Magistratura do Paraná (EMAP/PR). Pesquisadora no Projeto de Pesquisa Contratualização das Relações Familiares e das Relações Sucessórias. Advogada. E-mail: isabelanschiavon@hotmail.com
} 
Perpassam, pelas características do pacto antenupcial, aduzindo sobre a sua forma prescrita em lei, qual seja a escritura pública, com efeitos erga omnes, e sobre a sua função de formalizar a escolha por um regime de bens diverso do regime legal, sendo possível, inclusive a criação de um novo regime de bens pelo casal. Ademais, aduzem, as autoras sobre situação de nulidade e ineficácia do pacto antenupcial, passando a investigar as possibilidades e os limites da autonomia privada no pacto, tendo como perspectiva a situação jurídica no caso concreto à luz da hermenêutica constitucional.

As questões controvertidas sobre o pacto vão colidir com a eficácia do pacto antenupcial ajustado e não seguido do casamento, todavia permanecendo o casal em união estável, caso em que, pela interpretação estrita do artigo 1.653 do Código Civil, seria considerado ineficaz. Porém, as autoras trazem como argumentos favoráveis a eficácia a vontade exteriorizada pelo casal derivada da autonomia privada, havendo posterior formação de família, ainda que não formal, bem como que, nos termos dos artigos 112 e 170 do Código Civil, privilegia-se a intenção consubstanciada na declaração de vontade e há a possibilidade de conversão de um negócio jurídico em outro quando presentes os requisitos.

Da leitura do artigo, observam-se decisões judiciais que conferem eficácia à vontade manifestada pelo casal somente na certidão de casamento, no caso de pacto antenupcial ausente, trazendo a argumentação no sentido de considerar eficaz o regime registrado em certidão de casamento com vistas à garantia da autonomia privada por meio da vontade manifestada pelas partes desde que condizente com o comportamento dos cônjuges entre eles e perante terceiros. No que tange às cláusulas que preveem modificações no regime após certo lapso de tempo, observam que o sistema jurídico apenas admite mediante autorização judicial com pedido motivado, ressalvados os direitos de terceiros.

No que tange às questões controvertidas sobre aspectos patrimoniais no pacto antenupcial, Ana Carla Harmatiuk Matos e Ana Carolina Brochado Teixeira asseveram que na eleição de separação obrigatória de bens para os casamentos de septuagenários é possível que se afaste a Súmula 377 do Supremo Tribunal Federal ao se estipular o regime de separação convencional de bens no pacto antenupcial ou no contrato de convivência, todavia os efeitos desse regime somente incidem em caso de divórcio, não se aplicando pra fins sucessórios.

Ainda sobre questões patrimoniais no pacto, as autoras abordam sobre a retroatividade das disposições patrimoniais restritivas e sobre situações de nulidade do pacto em havendo contravenção à disposição absoluta de lei, nesse sentido, não sendo possível que se transacione sobre direitos da personalidade do cônjuge e nem sobre situações jurídicas fundamentadas na solidariedade social. Sobre as cláusulas sucessórias no pacto antenupcial, sustentam que não podem contrariar disposição legal sob pena de nulidade.

Em relação às disposições existenciais no pacto antenupcial, as autoras, trazem possibilidades e limites, afirmando que o pacto antenupcial se configura como um negócio jurídico dúplice que com alicerce na autonomia privada tem sua função voltada para a situação concreta e a casuística, com vistas tanto à tutela do livre desenvolvimento da personalidade, em seu aspecto 
existencial, quanto à garantia da livre iniciativa, em seu aspecto patrimonial.

Em notas conclusivas, Ana Carla Harmatiuk Matos e Ana Carolina Brochado Teixeira sustentam que a inauguração da hermenêutica constitucional, tendo a pessoa humana como centralidade no ordenamento jurídico, ampliou os espaços de liberdade para realização mútua do casal, com escopo na igualdade e na solidariedade familiar; que o pacto antenupcial é o instrumento jurídico que melhor possibilita a exteriorização do projeto familiar em sua realização patrimonial e pessoal; que as controvérsias no pacto devem ser solucionadas em observando a realidade concreta que se apresenta; por fim, que privatização da família e a limitação da intervenção do Estado nas relações familiares tornou o pacto antenupcial em um importante instrumento para autodeterminação da vida privada.

Como citar: SCHIAVON, Isabel Nabas. Pacto antenupcial na hermenêutica civil-constitucional. Revista do Direito Público, Londrina, v. 16, n. 3, p. 248-250, dez. 2021. Resenha da obra de: MENEZES, Joyceane Bezerra de; CICCO, Maria Cristina de; RODRIGUES, Francisco Luciano Lima (coord.). Direito civil na legalidade constitucional: algumas aplicações. Indaiatuba: Foco, 2021. 